\title{
14-Helical Folding in a Cyclobutane-Containing $\beta$-Tetrapeptide
}

\author{
Sandra Izquierdo, ${ }^{\dagger}$ Marcelo J . Kogan, ${ }^{\ddagger}$ Teodor Parella, ${ }^{\S}$ Albertina G. Moglioni, ${ }^{\dagger}, \|$ \\ Vicenç Branchadell, ${ }^{\dagger}$ Ernest Giralt, ${ }^{\ddagger} \perp$ and Rosa M. Ortuño*,† \\ Departament de Química, Universitat Autònoma de Barcelona, 08193 Bellaterra, Barcelona, Spain, \\ Institut de Recerca Biomèdica de Barcel ona, Parc Científic de Barcel ona, J osep Samitier, 1-5, \\ 08028 Barcel ona, Spain, Servei de Ressonància Magnètica Nuclear, Universitat Autònoma de Barcel ona, \\ 08193 Bellaterra, Barcel ona, Spain, and Departament de Química Orgànica, U niversitat de Barcel ona, \\ Martí i Franquès 1-11, 08028-Barcel ona, Spain \\ rosa.ortuno@uab.es
}

Received February 11, 2004

\begin{abstract}
The efficient synthesis of tetrapeptide 5 containing, in alternation, cyclobutane and $\beta$-alanine residues is described. NMR experiments both at low temperature in $\mathrm{CDCl}_{3}$ and at $298 \mathrm{~K}$ in DMSO$\mathrm{d}_{6}$ solutions show the contribution of a strong hydrogen bond in the folded major conformation of 5. Temperature coefficients and diffusion times point out a hydrogen bond involving the $\mathrm{NH}$ proton from the cycl obutane residue $\mathbf{1}$ whereas NOEs manifest the high rigidity of the central fragment of the molecule and are compatible with a 14-membered macrocycle. Theoretical calculations predict a most stable folded conformation corresponding to a 14-helix stabilized by a hydrogen bond between $\mathrm{NH}_{10}$ in the first residue and $\mathrm{OC}_{25}$ in the third residue. This structure remains unaltered during the molecular dynamics simulation at $298 \mathrm{~K}$ in chloroform. All these results provide evidence for a 14-helical folding and reveal the ability of cis-2-aminocyclobutane carboxylic acid residues to promote folded conformations when incorporated into $\beta$-peptides.
\end{abstract}

\section{Introduction}

The secondary structure of peptides, i.e., helices, turns, and sheetlike conformations, are determinant factors of their biological properties both in $\alpha$-and in $\beta$-amino acid derivatives. ${ }^{1}$ Oligomers of $\beta$-amino acids ( $\beta$-peptides) are more resistant to enzymatic hydrolysis and degradation than $\alpha$-peptides, and this property is of interest for the construction of biomimetic polymers. ${ }^{2}$ Recently, the relevant antimicrobial and hemolytic activity of amphiphilic $\beta$-oligomers has been shown, thus prompting the research in this field. ${ }^{3}$

The design of $\beta$-peptides for biological applications has ther efore been encouraged. Besides the use of additional functional groups or bulky substituents, hetero- ${ }^{4}$ or carbocyclic residues have been employed for trying to

\footnotetext{
† Departament de Química, Universitat Autònoma de Barcelona.

* Institut de Recerca Biomèdica de Barcel ona.

$\S$ Servei de Ressonància Magnètica Nuclear, Universitat Autònoma de Barcelona.

" Present address: Departamento de Química Orgánica, Facultad de Farmacia y Bioquímica, Universidad de Buenos Aires, Argentina.

$\perp$ Departament de Química Orgànica, Universitat de Barcelona.

(1) For reviews on the $\beta$-peptide secondary structure, see: (a) Gellman, S. H. Acc. Chem. Res. 1998, 31, 173. (b) DeGrado, W. F.; Schneider, J . P.; Hamuro, Y. J . Peptide Res. 1999, 54, 206. (c) Cheng, R. P.; Gellman, S. H.; DeGrado, W. F. Chem. Rev. 2001, 101, 3219. (d) Martinek, T. A.; Fülop, F. Eur. J . Biochem. 2003, 270, 3657.

(2) (a) Seebach, D.; Overhand, M.; Kühnle, F. N. M.; Martinoni, B.; Oberer, L. Hommel, U : Widmer, H. Hev. Chim. Acta 1996, 79, 913. (b) Hintermann, T.; Seebach, D. Synlett 1997, 437. (c) Seebach, D.; Abele, S.; Schreiber, J . V.; Martinoni, B.; Nussbaum, A. K.; Schild, H.; Schulz, H.; Henneke, H.; Woessner, R.; Bitsch, F. Chimia 1998, 52, 734. (d) Rueping, M.; Mahajan, Y.; Sauer, M.; Seebach, D. ChemBioChem 2002, 3, 257. (e) Schreiber, J. V.; Frackennpohl, J.; Moser, F.; Fleischmann, T.; Kohler, H.-P. E. Seebach, D. ChemBioChem 2002, 3, 424.
}

induce the folding of the $\beta$-peptidic chains. Foldamers that display specific conformations at short lengths, i.e., less than 10 residues, are especially interesting since they may have medicinal applications such as for disruption of specific protein-protein interactions. Fleet et al. have described left-handed helical structures stabilized by 10membered hydrogen-bonded rings (10-helix) for oxetane $\beta$-amino acid hexamers. ${ }^{4 e} \beta$-Oligopeptides consisting of 2-aminocyclopentanecarboxylic acid (ACPC) $)^{5}$ and 2-aminocyclohexanecarboxylic acid $(\mathrm{ACHC})^{6}$ have been prepared and investigated. Gellman described that oligomers composed of trans-ACPC residues adopt a 12-helix conformation, ${ }^{5 a}$ whereas F ülop showed that the pentamer

(3) (a) Werder, M.; Hausre, H.; Abele, S.; Seebach, D. Helv. Chim. Acta 1999, 82, 1774. (b) Hamuro, Y.; Schneider, J . P.; DeGrado, W. F. J . Am. Chem. Soc. 1999, 121, 12300. (c) Porter, E. A.; Weisblum, B.; Gellman, S. H. J. Am. Chem. Soc. 2002, 124, 7324. (d) Raguse, T. L.; Porter, E. A.; Weisblum, B.; Gellman, S. H. J . Am. Chem. Soc. 2002, $124,12774$.

(4) (a) Haque, T. S.; Little, J . C.; Gellman, S. H. J . Am. Chem. Soc. 1996, 118, 6975. (b) Huck, B. R.; Langenhan, J . M.; Gellman, S. H. Org. Lett. 1999, 1, 1717. (c) Chung, Y. J .; Huck, B. R.; Christianson, L.; Stanger, H. E.; Krauthäuser, S.; Powell, D. R.; Gellman, S. H. J. Am. Chem. Soc. 2000, 122, 3995. (d) Fisk, J . D.; Powell, D. R.; Gellman, S. H. J. Am. Chem. Soc. 2000, 122, 5443. (e) Claridge, T. D. W.; Goodman, J. M.; Moreno, A.; Angus, D.; Barker, S. F.; Taillefumier, C.; Watterson, M. P.; Fleet, G. W. J . Tetrahedron Lett. 2001, 42, 4251. (f) Porter, E. A.; Wang, X.; Schmit, M.; Gellman, S. H. Org. Lett. 2002 4, 3317. (g) Langenhan, J. M.; Guzei, I. A.; Gellman, S. H. Angew. Chem., Int Ed. 2003, 42, 2402.

(5) (a) Appella, D. H.; Christianson, L. A.; Klein, D. A.; Richards, M. R.; Powell, D. R.; Gellman, S. H. J . Am. Chem. Soc. 1999, 121, 7574 (b) LePlae, P. R.; Fisk, J . D.; Porter, E. A.; Weisblum, B.; Gellman, S. H. J . Am. Chem. Soc. 2002, 124, 6820. (c) Woll, M. G.; Fisk, J. D.; LePlae, P. R.; Gellman, S. H. J . Am. Chem. Soc. 2002, 124, 12447. (d) Park, J .-S.; Lee, H.-S.; Lai, J . R.; Kim, B. M.; Gellman, S. H. J . Am. Chem. Soc. 2003, 125, 8539. (e) Martinek, T. A.; Tóth, G. K.; Vass, E.; Hollósi, M.; Fülop, F. Angew. Chem. Int. Ed. 2002, 41, 1718. 


\section{SCHEME 1a}

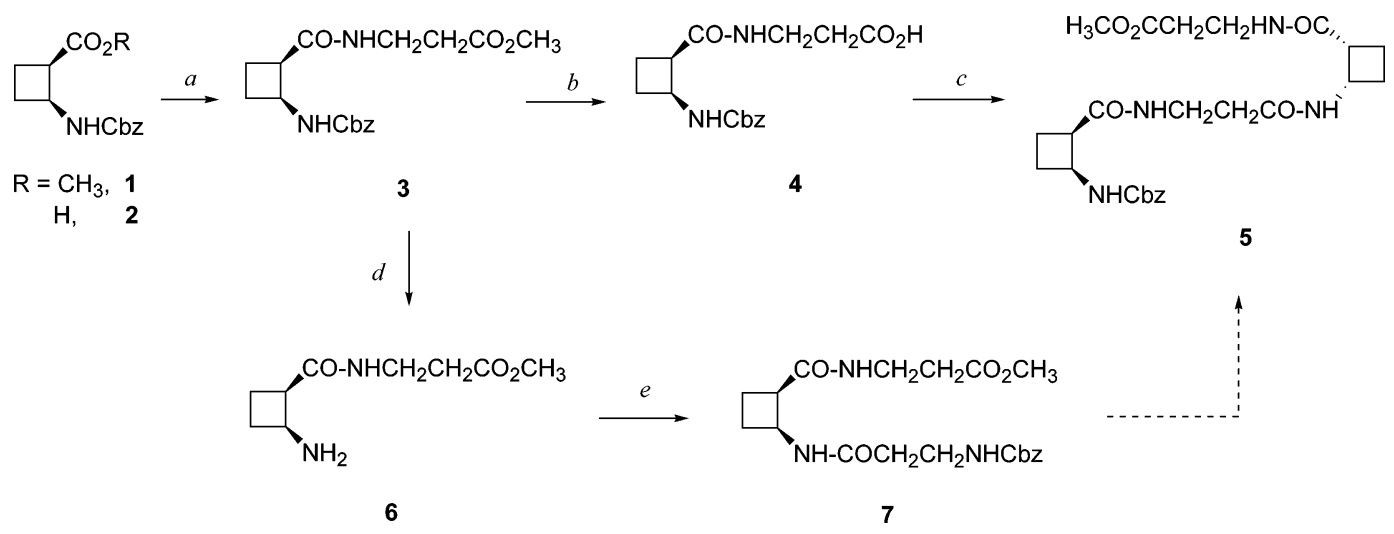

a Reagents and conditions: (a) $\mathrm{HCl} \cdot \mathrm{H}_{2} \mathrm{~N}\left(\mathrm{CH}_{2}\right)_{2} \mathrm{CO}_{2} \mathrm{Me}$, TEA, $\mathrm{HOBt}, \mathrm{DEC}, \mathrm{DMF}, \mathrm{rt}, 20 \mathrm{~h}, 86 \%$; (b) $0.25 \mathrm{M} \mathrm{NaOH}, 1: 10 \mathrm{THF}-\mathrm{H}_{2} \mathrm{O}, 0{ }^{\circ} \mathrm{C}$, 1 h, 100\%; (c) 6, HOBt, DEC, TEA, DMF, rt, 72 h, 60\%; (d) $\mathrm{H}_{2}, \mathrm{Pd} / \mathrm{C}, \mathrm{MeOH}, 2 \mathrm{~atm}, 94 \%$; (e) $\mathrm{CbzNH}\left(\mathrm{CH}_{2}\right)_{2} \mathrm{CO}_{2} \mathrm{H}, \mathrm{HOBt}, \mathrm{DEC}, \mathrm{DMF}, \mathrm{rt}$, $20 \mathrm{~h}, 34 \%$

and heptamer of cis-ACPC adopt a self-stabilizing sixstrand secondary structure in solution. ${ }^{\text {5e }}$ The tetramer of trans-ACHC displayed a 14-helix secondary structure both in the solid state ${ }^{6 b}$ and in methanol solution. ${ }^{6 c}$ Shortlengthed amphiphilic $\beta$-peptides prepared by DeGrado et al. have also shown a 14-helix disposition, this conformation being essential for their antibacterial activity. ${ }^{3 b}$

In addition to these results, there are no reports in the literature on the synthesis and structural study of cyclobutane containing $\beta$-oligomers in addition to our works. 7,8 Moreover, although theor etical calculations on the structure of $\beta$-peptide models have been reported, ${ }^{9}$ to the best of our knowledge, theoretical studies on $\beta$-peptides containing cycl obutane residues have not yet been reported.

According to our research program on the synthesis and structural study of conformationally constrained amino acids and related peptidomimetics, ${ }^{10}$ we have synthesized the cis-cycl obutane $\beta$-amino acid derivative $\mathbf{1}^{7}$ and its enantiomer (Scheme 1). ${ }^{8}$ We then envisioned the synthesis of cyclobutane $\beta$-peptides to test the ability of the cycl obutane unit to constrain confomationally the oligomers derived inducing molecular foldings. Thus, we prepared the dipepti de $\mathbf{3}$ (Scheme 1) from the amino acid $\mathbf{2}$ and $\beta$-Ala-OMe. X-ray diffraction analysis showed a

(6) (a) Appella, D. H.; Barchi, J . J ., J r.; Durell, S. R.; Gellman, S. H. J. Am. Chem. Soc. 1999, 121, 2309. (b) Appella, D. H.; Christianson, L. A.; Karle, I. L.; Powell, D. R.; Gellman, S. H. J . Am. Chem. Soc 1999, 121, 6206. (c) Barchi, J. J ., J r.; Huang, X.; Appella, D. H.; Christianson, L. A.; Durell, S. R.; Gellman, S. H. J . Am. Chem. Soc 2000, 122, 2711. (d) Appella, D. H.; LePlae, P. R.; Raguse, T. L.; Gellman, S. H. J . Am. Chem. Soc. 2000, 65, 4766. (e) Raguse, T. L.; Porter, E. A.; Weisblaum, B.; Gellman, S. H. J . Am. Chem. Soc. 2002, 124, 12774. (f) Raguse, T. L.; Lai, J . R.; Gellman, S. H. J . Am. Chem. Soc. 2003, 125, 5592.

(7) (a) Martín-Vilà, M.; Minguillón, C.; Ortuño, R. M. Tetrahedron: Asymmetry 1998, 9, 4291. (b) Martín-Vilà, M.; Muray, E.; Aguado, G. P.: Álvarez-Larena, A.; Branchadell, V.; Minguillón, C.; Giralt, E.; Ortuño, R. M. Tetrahedron: Asymmetry 2000, 11, 3569.

(8) Izquierdo, S.; Martín-Vilà, M.; Moglioni, A. G.; Branchadell, V.; Ortuño, R. M. Tetrahedron: Asymmetry $2002,13,2403$.

(9) (a) Bode, K. A.; Applequist, J. Macromolecules 1997, 30, 2144 (b) Wu, Y.-D.; Wang, D.-P. J . Am. Chem. Soc. 1998, 120, 13485. (b) Möhle, K.; Gunther, R.; Thormann, M.; Sewald, N.; Hofmann, H. J. Biopolymers 1999, 50, 167. (c) Christianson, L. A.; Lucero, M. J .; Appella, D. H.; Klein, D. A.; Gellman, S. H. J . Comput. Chem. 2000, 21, 763. (c) Daura, X.; Gademann, K.; Schäfer, H.; J aun, B.; Seebach, D.; van Gunsteren, W. F. J . Am. Chem. Soc. 2001, 123, 2393. (d) Lin . .-Q.; Luo, S.-W.; Wu, Y.-D. J . Comput. Chem. 2002, 23, 1551. (e) Beke T.; Csizmedia, I. G.; Perczel, A. J . Comput. Chem. 2004, 25, 285. hairpin-like disposition of the molecule in the crystal packing, favored by the formation of intermolecular hydrogen bonds. ${ }^{7 b}$ This first result was encouraging since it was al ready known the low propensity of the $\beta$-alanine residue for bend formation in the crystal state ${ }^{11}$ and the formation of a disordered structure without extensive intramolecular hydrogen bonding in aqueous solution. ${ }^{12}$ Nevertheless, NMR studies in several solvents did not suggest either the existence of inter- or intramolecular hydrogen bonds or a conformational bias in solution for dipeptide 3, even though this result was not surprising taking into account its small size.

We decided, therefore, to prepare and study a $\beta$-oligomer with extended length. Thus, in this paper, we describe the efficient synthesis of tetrapeptide $\mathbf{5}$ and its conformational analysis on the basis of NMR experiments and molecular modeling calculations. These studies provide evidence for a 14-helical folding of this molecule.

\section{Results and Discussion}

Synthesis of $\boldsymbol{\beta}$-Tetrapeptide 5 . Two synthetic ways were explored to prepare 5 (Scheme 1). The route involving a linear sequence passes through tripeptide $\mathbf{7 .}$ Thus, benzyl carbamate in $\mathbf{3}$ was hydrogenolyzed in the presence of palladium on charcoal to afford amine $\mathbf{6}$. This compound was coupled with $\mathrm{Cbz}-\beta$-Ala by treatment with excess 1-(3-dimethylaminopropyl)-3-ethyl car bodiimide (DEC) as dehydrating agent and 1 equiv of 1-hydroxybenzotriazole (HOBt) as a catalyst in anhydrous DMF solution at room temperature for $20 \mathrm{~h}$ giving 7, in $34 \%$ yield, as a pasty solid difficult to purify. This poor result

(10) For some selected recent works, see: (a) Martín-Vilà, M.; Hanafi, N.; J iménez, J. M.; Álvarez-Larena, A.; Piniella, J. F.; Branchadell, V.: Oliva, A.; Ortuño, R. M.J. Org. Chem. 1998, 63, 3581. (b) Rifé, J .; Ortuño, R. M. Lajoie, G. J . Org. Chem. 1999, 64, 8958. (c) Moglioni, A. G.; García-Expósito, E.; Aguado, G. P.; Parella, T.; Moltrasio, G. Y.; Branchadell, V.; Ortuño, R. M.J . Org. Chem. 2000 65, 3934. (d) Illescas, B.; Rifé, J .; Ortuño, R. M.; Martín, N. J . Org. Chem. 2000, 65, 6246. (e) Moglioni, A. G.; Muray, E.; Castillo, J . A.; Álvarez-Larena, A.; Moltrasio, G. Y.; Branchadell, V.; Ortuño, R. M. J. Org. Chem. 2002, 67, 2402. (f) Aguado, G. P.; Moglioni, A. G.; Ortuño, R. M. Tetrahedron: Asymmetry 2003, 14, 217.

(11) Pavone, V.; Di Blasio, B.; Lombardi, A.; Isernia, C.; Pedone, C.; Benedetti, E.; Valle, G.; Crisma, M.; Toniolo, C.; Kishore, R. J. Chem. Soc., Perkin Trans. 2 1992, 1233.

(12) Glickson, J . D.; Applequist, J . J . Am. Chem. Soc. 1971, 93, 3276.

5094 J. Org. Chem., Vol. 69, No. 15, 2004 
TABLE 1. Chemical Shifts, Coupling Constants, NOEs, and Temperature Coefficients for the NH Protons of the Predominant Conformer of 5

\begin{tabular}{ccccc}
\hline $\mathrm{NH}^{\mathrm{a}}$ & $\begin{array}{c}\delta^{\mathrm{b}} \\
(\mathrm{ppm})\end{array}$ & $\begin{array}{c}\mathrm{J} \\
(\mathrm{Hz})\end{array}$ & \multicolumn{1}{c}{$\mathrm{NOE}^{\mathrm{c}}$} & $\begin{array}{c}\Delta \delta / \Delta \mathrm{T}^{\mathrm{d}} \\
(\mathrm{ppp} / \mathrm{K})\end{array}$ \\
\hline $\mathrm{H}_{10}$ & $6.11(7.20)$ & 9.0 & $\mathrm{H}_{13 a}(\mathrm{w}), \mathrm{H}_{12 \mathrm{a}}(\mathrm{s}), \mathrm{H}_{12 b}(\mathrm{~m})$ & -2.2 \\
$\mathrm{H}_{16}$ & $6.88(7.65)$ & 6.0 & $\mathrm{H}_{18 a, b}(\mathrm{~m}), \mathrm{H}_{17 a, b}(\mathrm{~s}), \mathrm{H}_{14}(\mathrm{~s})$ & -3.7 \\
$\mathrm{H}_{20}$ & $7.18(7.94)$ & 8.2 & $\mathrm{H}_{22 b}(\mathrm{~s}), \mathrm{H}_{21}(\mathrm{~m}), \mathrm{H}_{18 b}(\mathrm{~s})$, & -3.5 \\
& & & $\mathrm{H}_{17 a, b}(\mathrm{w})$ & \\
$\mathrm{H}_{26}$ & $6.40(7.73)$ & 6.0 & $\mathrm{H}_{28 \mathrm{a}}(\mathrm{m}), \mathrm{H}_{27 a, b}(\mathrm{~s}), \mathrm{H}_{24}(\mathrm{~s})$ & -3.4
\end{tabular}

a See Figure 1 for atom numeration. ${ }^{b} / \mathrm{n} \mathrm{CDCl}_{3}$ at $260 \mathrm{~K}$ and, in parentheses, in DMSO- $d_{6}$ at $298 \mathrm{~K} .{ }^{c} \operatorname{In~} \mathrm{CDCl}_{3}$ at $260 \mathrm{~K}$ and in DMSO- $d_{6}$ at 298 K. w: weak. m: medium. s: strong. ${ }^{d}$ In $\mathrm{CDCl}_{3}$.

led us to investigate a shorter convergent route to synthesize 5. With this purpose, the methyl ester in $\mathbf{3}$ was hydrolyzed by using $0.25 \mathrm{M} \mathrm{NaOH}$ in a 1:10 THFwater solution to produce acid $\mathbf{4}$ without epimerization. This compound was condensed with amine $\mathbf{6}$ under similar conditions than above to afford the tetrapeptide 5 in $60 \%$ yield, which was purified by crystallization from ethyl acetate. Crystals were not suitable for X-ray diffraction analysis.

NMR Studies. Complete ${ }^{1} \mathrm{H}$ and ${ }^{13} \mathrm{C}$ resonance assignments were performed using conventional 2D techniques (COSY, HSQC, and HMBC experiments). Moreover, other NMR experiments (variable-temperature 2D NOESY/2D ROESY and measurement of temperature coefficients and apparent self-diffusion coefficients) were performed on $\mathbf{5}$ in order to state its conformational bias in solution. Two main conformations were observed in its ${ }^{1} \mathrm{H}$ NMR spectrum. However, variable-temperature NMR experiments in the 230-300 K were needed because of the large line broadening observed due to the strong chemical exchange cross-peaks detected in NOESY spectra at 270-300 K temperature. For the predominant conformation (>95\%), the NOE data observed at low temperature (Table 1) suggest hydrogen-bond interactions between the amide protons and carbonyl oxygen atoms. The large proton-proton coupling constants (9 $\mathrm{Hz}$ ) and the absence of NOE for $\mathrm{NH}_{10}-\mathrm{H}_{11}$ and $\mathrm{NH}_{20}-$ $\mathrm{H}_{21}$ are in agreement with a spatial anti disposition of the $\mathrm{NH}$ and the vicinal cyclobutane $\mathrm{CH}$ protons (see Figure 1 for atom numeration). Otherwise, the high chemical shift anisocrony observed for the methylene protons at $\mathrm{C}_{17}$ and $\mathrm{C}_{18}$ ( $\beta$-alanine residue) accounts for a remarkable rigidity of the $\mathrm{C}_{15}-\mathrm{N}_{20}$ segment of the molecule. In contrast, the other $\beta$-alanine residue ( $\mathrm{MeO}-$ $\mathrm{C}_{29}-\mathrm{C}_{28}-\mathrm{C}_{27}$ fragment) must be rather flexible according to the chemical shifts of the methylene protons (see the Experimental Section).

The temperature coefficients in $\mathrm{CDCl}_{3}$ solution suggest a stronger intramolecular hydrogen bond for $\mathrm{NH}_{10}([\Delta \delta /$ $\Delta \mathrm{T}]=2.2 \mathrm{ppb} / \mathrm{K})$ with respect to the other three $\mathrm{NH}$ protons (3.4-3.7 ppb/K). ${ }^{13}$

Chemical-exchange properties of exchangeable $\mathrm{NH}$ or hydroxyl spin systems have been also studied using diffusion-based NMR experiments. ${ }^{14}$ It has been demon-

(13) References for temperature coefficients in peptides and proteins: (a) Rothermund, S.; Weibhoff, H.; Beyermann, M.; Krause, E. Bienert, M.; Mugge, C.; Sykes, B. D.; Sonnichsen, F. D. J . Biomol . NMR 1996, 8, 93. (b) Baxter, N.-J .; Williamson, M. P.J . Biomol. NMR 1997 9, 359. (c) Cierpicki, T.; Otlewski, J J . Biomol. NMR 2001, 21, 249. (d) Cierpicki, T.; Zhukov, I.; Byrd, R. A.; Otlewski, J . J . Biomol. NMR 2002, 157, 178.

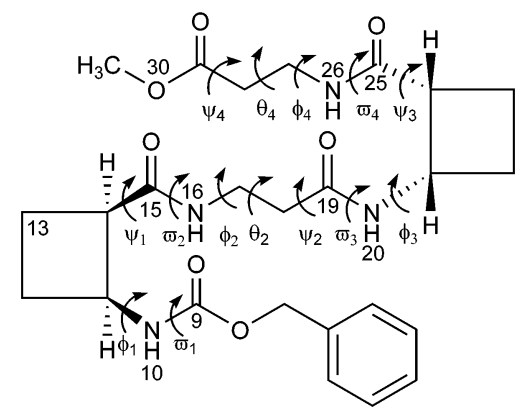

FIGURE 1. Structure of tetrapeptide $\mathbf{5}$ where atom numeration and torsional angles are defined.

strated that the observed apparent diffusion behavior of the $\mathrm{NH}$ resonances reflects the relative lifetimes of these protons in the peptide and the water environments ${ }^{15}$ and, therefore, provides a rapid and useful method for studying $\mathrm{NH}$ exchange rates and detect qual itative information about the different exchange sites of the molecule such as hydrogen bond strength and solvent accessibility properties.

In the absence of exchange, all proton resonances belonging to the same molecule present the same diffusi on behavior. However, in the presence of exchange, the $\mathrm{NHs}$ involved in exchange appear to have an intermediate character, since their apparent diffusion behavior lie between those of the large peptide and the small residual water molecules. The different decays observed for all $\mathrm{NH}$ resonances of $\mathbf{5}$ in 1D pulsed field gradient spin-echo (PFGSE) experiments account for their exchange properties. A series of diffusion experiments recorded with different diffusion times confirm the faster decay for all $\mathrm{NH}$ protons except for $\mathrm{NH}_{10}$. In addition, the $\mathrm{NH}_{10}$ proton decays in a similar way as observed for nonexchangeable protons evidencing the stronger hydrogen bonding properties of this proton in close analogy with the measured temperature coefficients (see the Supporting Information).

The minor conformation (less than 5\%) was difficult to study due to its low contribution. The major differential feature of its ${ }^{1} \mathrm{H}$ NMR spectrum with respect to the major conformer is the large upfield shift $(+0.9$ ppm) of the $\mathrm{NH}_{26}$ proton whereas the other $\mathrm{NH}$ protons show a slight downfield shift about -0.2 to $-0.5 \mathrm{ppm}$ and a stronger hydrogen bond for $\mathrm{NH}_{10}$ based on the temperature coefficients. This second conformation could be related to the cis-trans isomerism of the amide bonds.

In DMSO- $d_{6}$ solution, results were similar to those in $\mathrm{CDCl}_{3}$ although the molecule seems to be slightly more flexible according to the chemical shifts for the protons in the central $\beta$-alanine fragment (see the Supporting Information). Otherwise, the observed significant NOEs are the same than in $\mathrm{CDCl}_{3}$ (Table 1 ), and diffusion and NOESY experiments at $298 \mathrm{~K}$ show that $\mathrm{NH}_{10}$ is involved in a hydrogen bond stronger than the hydrogen bonds with the other amide protons.

Conformational Search. To determine the conformational space available to tetrapeptide $\mathbf{5}$, we performed

(14) (a) Cabrita, E. J .; Berger, S.; Bräuer, P.; Kärger, J . J . Magn. Reson. 2002, 157, 124. (b) Cabrita E. J .; Berger, S. Magn. Reson. Chem. 2002, 40, S122.

(15) Liu, M.; Toms, H. C.; Hawkes, G. E.; Nicholson, J . K.; Lindon, J. C. J . Biomol. NMR 1999, 13, 25. 


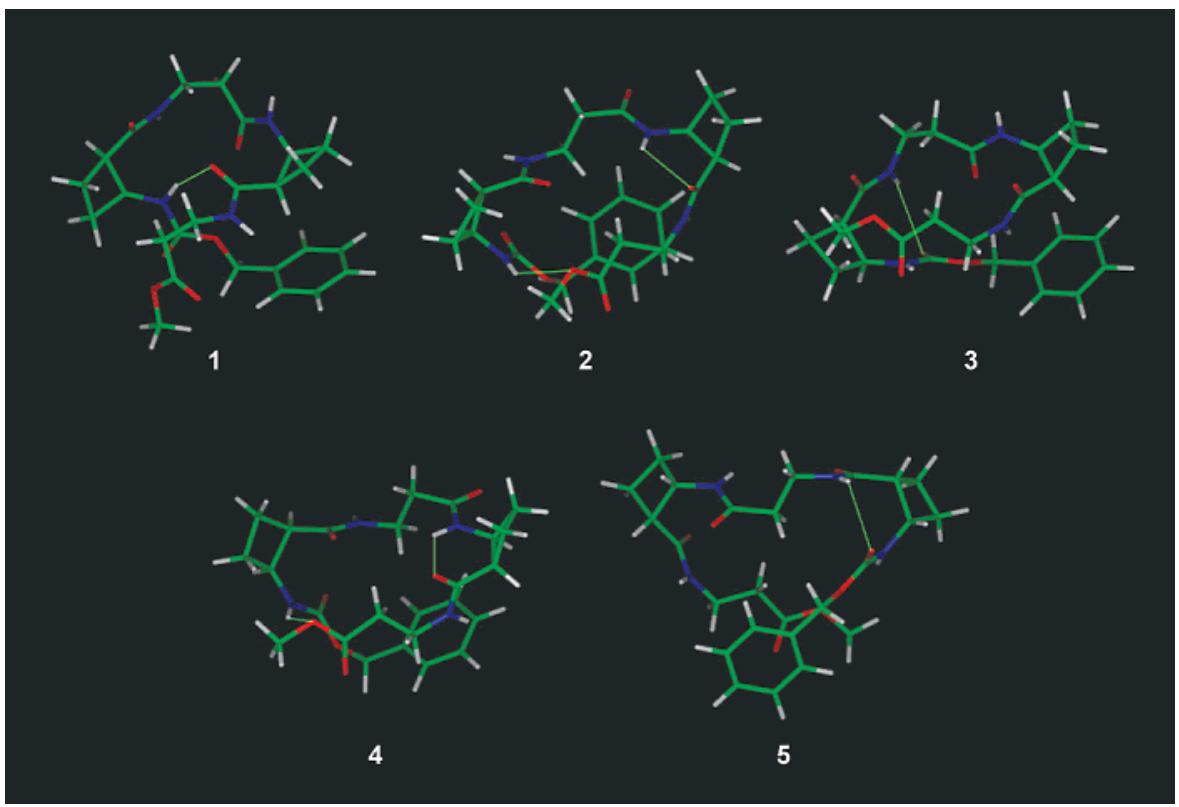

FIGURE 2. Stick conformational representation of minimum energy conformers of tetrapeptide $\mathbf{5}$ obtained after the ISA conformational search.

TABLE 2. Distancesa Between a Selection of NH and OC Atom Pairs for the Energy Minima Conformers (ISA) of Tetrapeptide 5

\begin{tabular}{cccccc}
\hline family $^{\mathrm{b}}$ & $\mathrm{E}^{\mathrm{c}}$ & $\mathrm{NH}_{10} \cdots \mathrm{OC}_{25}$ & $\mathrm{NH}_{10} \cdots \mathrm{O}_{30} \mathrm{C}$ & $\mathrm{NH}_{20} \cdots \mathrm{OC}_{25}$ & $\mathrm{NH}_{16} \cdots \mathrm{OC}_{9}$ \\
\hline $\mathbf{5}_{1}$ & 0.00 & 2.3 & 4.0 & 5.7 & 4.9 \\
$\mathbf{5}_{2}$ & 0.70 & 7.1 & 2.6 & 2.7 & 2.9 \\
$\mathbf{5}_{3}$ & 0.97 & 5.7 & 3.8 & 3.5 & 2.7 \\
$\mathbf{5}_{4}$ & 0.99 & 7.0 & 2.6 & 2.7 & 3.0 \\
$\mathbf{5}_{5}$ & 1.00 & 7.2 & 2.9 & 3.4 & 2.7 \\
a In & angstroms. b See Figure 2. ${ }^{c}$ Relative energies in kcal \\
mol $^{-1}$.
\end{tabular}

molecular dynamics with iterative simulated annealing ${ }^{16}$ (ISA) calculations. For the ISA a heating and cooling protocol was run five times, employing fully extended starting structures of $\mathbf{5}$ and CFF91 (implemented in DISCOVER 3) as force field, which was parametrized for cyclobutane derivatives and also for proteins. ${ }^{17}$

Structures corresponding to the energy minima (within a $2 \mathrm{kcal} / \mathrm{mol}$ window above the global minimum) were analyzed on the basis of the relevant geometric parameters, which are diagnostics of folding of the structure. A detailed study of the conformers obtained in the ISA search allows us to classify the minima energy conformers into five families $\left(5_{1}-5_{5}\right)$ (F igure 2 , Tables 2 and 3 ). The absolute minimum $5_{1}$ is clearly more stable $(0.7-1$ $\mathrm{kcal} / \mathrm{mol}$ ) than the other four conformers $\mathbf{5}_{2-5}$. Tables 2 and 3 present the relative energies and values of selected geometric parameters for all these structures. Conformer 51 presents an intramolecular hydrogen bond between $\mathrm{NH}_{10}$ and $\mathrm{OC}_{25}$ which could be indicative of the presence of a 14-helical structure. The participation of $\mathrm{NH}_{10}$ in a hydrogen bond is in agreement with the NMR results (temperature coefficients and diffusion experiments). On the other hand, in conformers $\mathbf{5}_{2-5}$ weak hydrogen bonds

(16) Corcho, F.; Filizola, M.; Pérez, J . J . Chem. Phys. Lett. 2000, $319,65$.

(17) (a) http://www.accel rys.com/support/life/discover/forcefield/cff9x refs.html. (b) Mal, B.; Nussinov, R. J . Mol. Biol. 2000, 296, 1091. are present (Table 2 , the distances between $\mathrm{NH}_{10} \cdot \mathrm{O}_{30} \mathrm{C}$, $\mathrm{NH}_{20} \cdots \mathrm{OC}_{25}, \mathrm{NH}_{16} \cdots \mathrm{OC}_{9}$ are lower than $2.8 \AA$ but higher than $2.5 \AA$ ).

The values determined for $\omega$ torsion angles suggest a predominant trans disposition for all the amide bonds in $5_{1-5}$ (Table 3 ). We have also analyzed the torsion angles belonging to the $\mathrm{N}_{16}-\mathrm{C}_{19}$ central $\beta$-alanine and to the $\mathrm{N}_{26}-\mathrm{C}_{29}$ terminal $\beta$-alanine (Table 3 ). Conformer 51 adopts a folded conformation in which the distance between the two cyclobutane rings is around $7 \AA$, while this distance would be $11 \AA$ in an extended hypothetical structure. The value of the torsion angle $\theta_{2}\left(-67^{\circ}\right)$ corresponds to a gauche conformation, which is in agreement with the $\theta_{2}$ value of a $\beta$-amino acid residue involved in a 14-helical structure. ${ }^{1 c, 9 a}$

On the other hand, the value $\theta_{4}=60^{\circ}$ corresponds to a gauche conformation avoiding the steric hindrance between the $\mathrm{C}_{11}-\mathrm{C}_{12}-\mathrm{C}_{13}-\mathrm{C}_{14}$ Cyclobutane ring and the $\mathrm{MeO}-\mathrm{C}_{29}-\mathrm{C}_{28}$ fragment that can be present in the anti conformation.

Even though the $\theta_{2}$ value in conformer $\mathbf{5}_{3}$ corresponds to a gauche conformation, a hydrogen bond to stabilize a 14-helical structure is not present, and the $\theta_{4}$ value corresponds to an anti disposition between the substituents. The structures $\mathbf{5}_{2,4,5}$ present a more extended conformation than $\mathbf{5}_{1}$ since the distances between the cyclobutanes are around $9 \AA$, as shown in Table 3 . The $\theta_{2}$ and $\theta_{4}$ torsional angles in these three conformers are close to $180^{\circ}$ corresponding to an anti disposition. In summary, regarding the rotation around the two central bonds of both $\beta$-alanine residues ( $\theta_{2}$ and $\theta_{4}$ torsion angles) $\mathbf{5}_{1}$ could be classified as gauche/gauche, $\mathbf{5}_{3}$ as gauche/anti, and the other three conformers $\mathbf{5}_{2,4,5}$ as anti/anti.

We have also analyzed other conformationally relevant torsional angles (Table 3) and distances (Supporting I nformation). F or all five conformations $\mathbf{5}_{1-5}$, protons in the pairs $\mathrm{NH}_{10} / \mathrm{H}_{11}$ and $\mathrm{NH}_{20} / \mathrm{H}_{21}$ are close to an anti disposition (i.e., $\phi_{1}$ and $\phi_{3}$ values around $140^{\circ}$, Table 3 ), which is in agreement with the NMR results (large 
TABLE 3. Characteristics ${ }^{a}$ of Energy Minima Conformers (ISA) for Tetrapeptide 5

\begin{tabular}{ccccccccccccrrr}
\hline family $^{\mathrm{b}}$ & $\mathrm{E}^{\mathrm{c}}$ & \multicolumn{1}{c}{$\omega_{1}$} & \multicolumn{1}{c}{$\omega_{2}$} & \multicolumn{1}{c}{$\phi_{2}$} & \multicolumn{1}{c}{$\theta_{2}$} & \multicolumn{1}{c}{$\Psi_{2}$} & $\omega_{3}$ & $\omega_{4}$ & $\phi_{4}$ & $\theta_{4}$ & $\Psi_{4}$ & $\mathrm{R}^{\mathrm{d}}$ & $\phi_{1}$ & $\phi_{3}$ \\
\hline $\mathbf{5}_{1}$ & 0.00 & -179 & 179 & 147 & -67 & -91 & -179 & 179 & 73 & 60 & -160 & 7.3 & 128 & -140 \\
$\mathbf{5}_{2}$ & 0.70 & 177 & -173 & -78 & 173 & -83 & -179 & -176 & 76 & 175 & -147 & 9.4 & -140 & 134 \\
$\mathbf{5}_{3}$ & 0.97 & 178 & 167 & 74 & 69 & 153 & 177 & -175 & 71 & 178 & 165 & 8.9 & -128 & -149 \\
$\mathbf{5}_{4}$ & 0.99 & 177 & -175 & -77 & 176 & -82 & 179 & -176 & 77 & 176 & 137 & 9.2 & -123 & 133 \\
$\mathbf{5}_{5}$ & 1.00 & 176 & -173 & 70 & -177 & 73 & 172 & -174 & 79 & 175 & 179 & 9.4 & -148 & -135
\end{tabular}

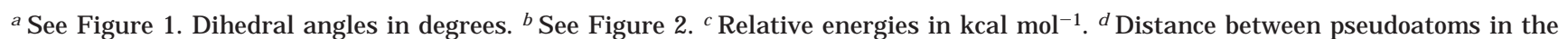
mass center of each cyclobutane ring in angstroms.

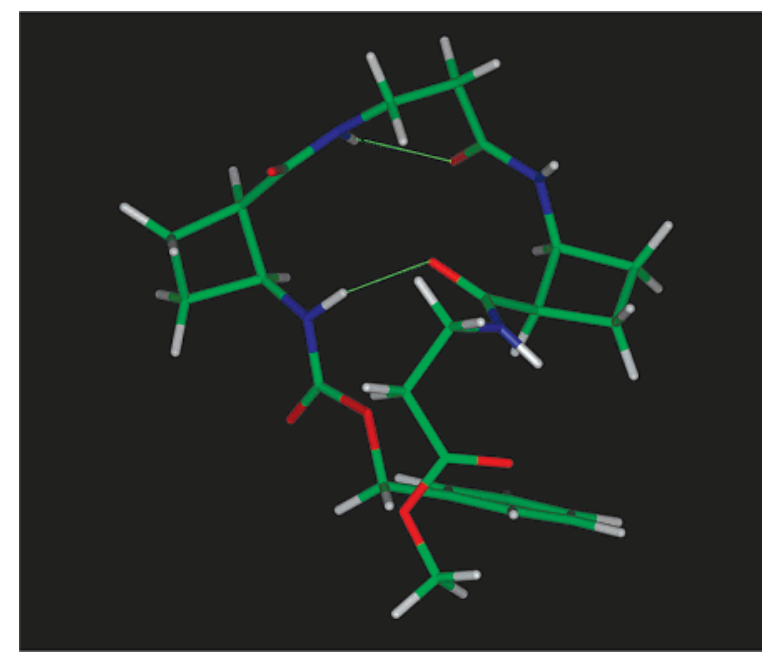

FIGURE 3. Structure of tetrapeptide $\mathbf{5}$ optimized at the B3LYP/6-31G(d) level of calculation.

proton-proton coupling constants $(9 \mathrm{~Hz})$ and absence of NOE s for $\mathrm{NH}_{10}-\mathrm{H}_{11}$ and $\mathrm{NH}_{20}-\mathrm{H}_{21}$ ). On the other hand, there is a good agreement between the observed qualitative NOE data (Table 1) and the calculated distances.

We have optimized the geometry of tetrapeptide $\mathbf{5}$ using the density functional B3LYP ${ }^{18}$ method with the 6-31G(d) basis set using the Gaussian-98 program. ${ }^{19}$ The absolute minimum obtained in the conformational search with the CFF 91 force field $\mathbf{5}_{1}$ has been taken as a starting point for this optimization. The obtained structure, which is shown in Figure 3, maintains the 14-helical structure, with a hydrogen bond distance $\mathrm{NH}_{10} \cdots \mathrm{OC}_{25}$ slightly shorter (2.01 $\AA$ ) than the one obtained with CFF91 (2.11 $\AA)$. The main differences between the B 3 L YP and CFF 91 structures are in the orientation of the phenyl ring of $\mathrm{Cbz}$ group and in the $\psi_{3}$ dihedral angle, which differs by $39.4^{\circ}$ from one structure to another. Moreover, at the B3LYP level of calculation, the $\mathrm{NH} \cdots \mathrm{O}$ distances corresponding

(18) (a) Becke, A. D. J . Chem. Phys. 1993, 98, 5648. (b) Lee, C.; Yang, W.; Parr, R. G. Phys. Rev. B 1988, 37, 785.

(19) Frisch, M. J.; Trucks, G. W.; Schlegel, H. B.; Scuseria, G. E.; Robb, M. A.; Cheeseman, J . R.; Zakrzewski, V. G.; Montgomery, J . A. J r.; Stratmann, R. E.; Burant, J. C.; Dapprich, S.; Millam, J. M.; Daniels, A. D.; Kudin, K. N.; Strain, M. C.; Farkas, O.; Tomasi, J .; Barone, V.; Cossi, M.; Cammi, R.; Mennucci, B.; Pomelli, C.; Adamo, C.; Clifford, S.; Ochterski, J .; Petersson, G. A.; Ayala, P. Y.; Cui, Q.; Morokuma, K.; Malick, D. K.; Rabuck, A. D.; Raghavachari, K.; Foresman, J. B.; Cioslowski, J .; Ortiz, J . V.; Stefanov, B. B.; Liu, G.; Liashenko, A.; Piskorz, P.; Komaromi, I.; Gomperts, R.; Martin, R. L.; Fox, D. J .; Keith, T.; Al-Laham, M. A.; Peng, C. Y.; Nanayakkara, A.; Gonzalez, C.; Challacombe, M.; Gill, P. M. W.; J ohnson, B. G.; Chen, W.; Wong, M. W.; Andres, J . L.; Head-Gordon, M.; Replogle, E. S.; Pople, J. A. Gaussian 98, revision A.6; Gaussian, Inc.: Pittsburgh, PA, 1998. to $\mathrm{NH}_{16} \cdots \mathrm{OC}_{19}(2.14 \AA)$ and $\mathrm{NH}_{26} \cdots \mathrm{OC}_{29}(2.32 \AA)$ are notably shorter than the values obtained with CFF91 (see Table 2).

Molecular Dynamics Calculations. To study the dynamic behavior of the most stable family of conformers of $\mathbf{5}$, the lowest energy conformer of $\mathbf{5}_{1}$ (resulting from the Iterative Simulated Anneal ing conformational search) was taken as the starting structure for a 1 ns roomtemperature molecular dynamics calculation using an explicit chloroform solvent model. We analyzed al ong the trajectory those geometric parameters diagnostic for fol ding. The distance between $\mathrm{NH}_{10}$ and $\mathrm{OC}_{25}$ found in the resulting conformer $\mathbf{5}_{1}$ remained almost constant, around $2.5 \AA$, during the molecular dynamics (Figure $4 A$ ). On the other hand, conformer $\mathbf{5}_{1}$ showed no major fluctuations of dihedral angles $\Psi_{2}, \theta_{2}, \phi_{2}, \theta_{4}$, and $\Psi_{4}$, while $\phi_{4}$ showed a considerable degree of fluctuation (Figure $4 B$ ). These results are in agreement with NMR data that strongly suggests that $\mathrm{C}_{15} \mathrm{~N}_{20}$ segment of the molecule is more rigid than the $\mathrm{MeO}-\mathrm{C}_{29}-\mathrm{C}_{28}-\mathrm{C}_{27}$ fragment.

\section{Concluding Remarks}

The presence of cyclobutane residues in tetrapeptide 5 promotes the adoption of a folded major conformation in solution. Thus, according to theoretical calculations (ISA, DFT), the most stable conformation corresponds to a 14-helix disposition. Moreover, molecular modeling al lowed us to establish that the $\mathrm{NH}_{10}$ proton is involved in a hydrogen bond with $\mathrm{OC}_{25}$ stabilizing the formation of a 14-helical structure. These results are in excellent agreement with the temperature coefficients and data from diffusion-based NMR experiments, which show indeed the participation of $\mathrm{NH}_{10}$ in a strong hydrogen bond in the predominant (>95\%) conformation in $\mathrm{CDCl}_{3}$ and DMSO- $\mathrm{d}_{6}$ solution. Furthermore, the observed NOEs are compatible with the 14-helix-type structure proposed for 5 .

\section{Experimental Section}

Acid 4. A solution of $0.25 \mathrm{M} \mathrm{NaOH}(7.2 \mathrm{~mL}, 1.8 \mathrm{mmol})$ was added to an ice-cool ed solution of dipeptide $3^{7 \mathrm{~b}}(360 \mathrm{mg}, 1.1$ $\mathrm{mmol})$ in 1:10 THF $-\mathrm{H}_{2} \mathrm{O}(198 \mathrm{~mL})$. The mixture was stirred at $0{ }^{\circ} \mathrm{C}$ for $3 \mathrm{~h}$. Then, the reaction mixture was washed with four portions of dichloromethane, $2 \mathrm{M} \mathrm{HCl}$ was subsequently added to the aqueous phase to reach $\mathrm{pH} \mathrm{2}$, and the acidresultant solution was extracted with six portions of dichloromethane. The combined organic extracts were dried over anhydrous $\mathrm{MgSO}_{4}$, and solvent was evaporated at reduced pressure to afford quantitatively acid $\mathbf{4}(340 \mathrm{mg})$ : crystals; $\mathrm{mp}$ $120-122{ }^{\circ} \mathrm{C}$ (from ethyl acetate-pentane); $[\alpha]_{D}-86$ (c 1.0 , methanol); $500 \mathrm{MHz}{ }^{1} \mathrm{H}$ NMR $\left(\mathrm{CDCl}_{3}\right) \delta 1.89(\mathrm{~m}, 1 \mathrm{H}), 2.33$ $(m, 1 H), 2.47(m, 2 H), 3.27(m, 1 H), 3.35(m, 1 H), 3.62(m$, $2 \mathrm{H}), 4.46(\mathrm{q}, J=9 \mathrm{~Hz}, 1 \mathrm{H}), 5.07(\mathrm{dd}, J=12 \mathrm{~Hz}, 1 \mathrm{H}), 5.10(\mathrm{~d}$, $\mathrm{J}=12 \mathrm{~Hz}, 1 \mathrm{H}), 6.02(\mathrm{~d}, \mathrm{~J}=9 \mathrm{~Hz}, 1 \mathrm{H}), 6.83($ broad s, $1 \mathrm{H})$, 


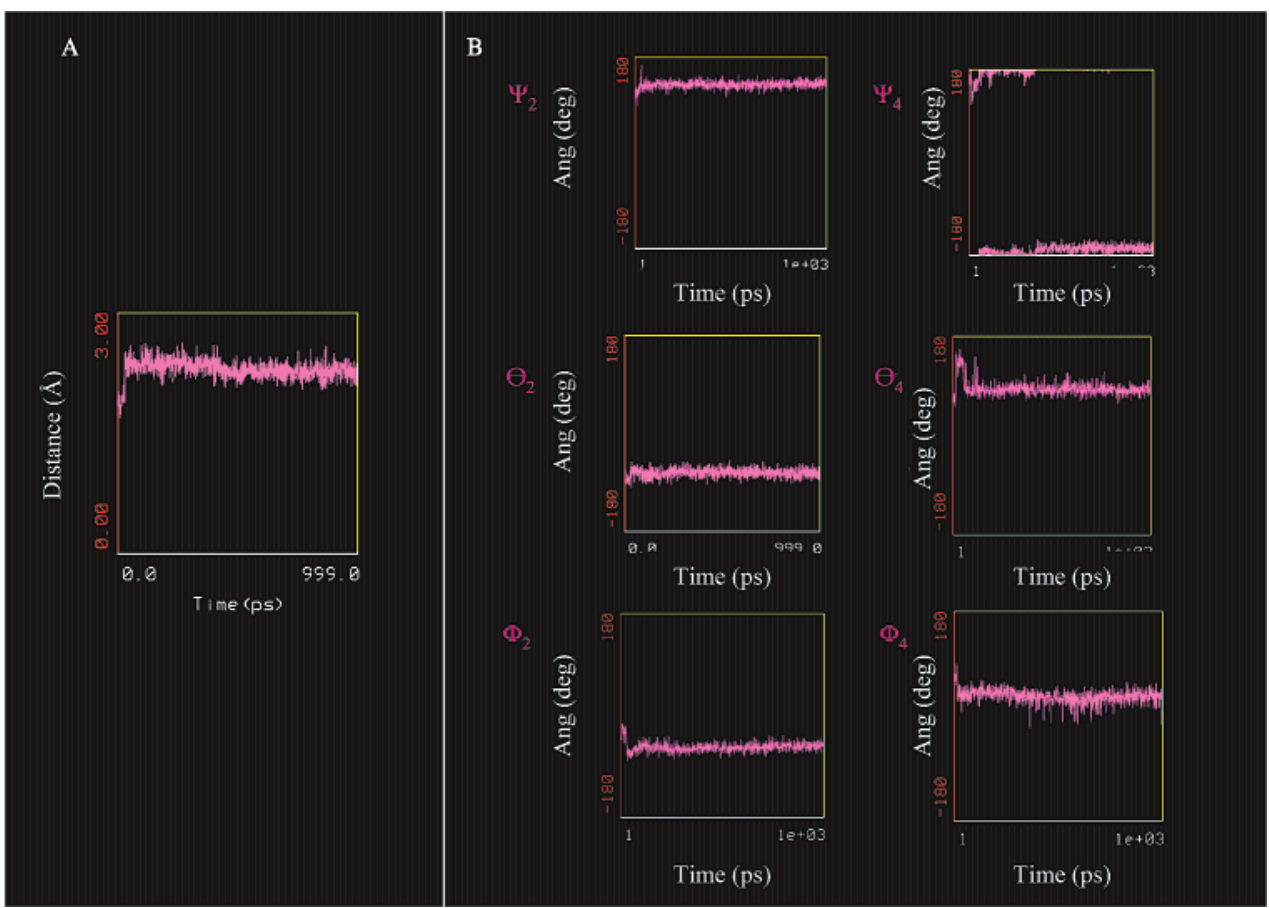

FIGURE 4. Values of a selection of geometric parameters diagnostic for the molecule folding of the conformer $\mathbf{5}_{1}$ as a function of time in a molecular dynamics simulation at $298 \mathrm{~K}$ in chloroform: (A) distance between $\mathrm{NH}_{\cdots} \cdot \mathrm{OC}_{25}$; (B) torsion angles belonging to the $\mathrm{N}_{16}-\mathrm{C}_{19}$ central $\beta$-alanine and to the $\mathrm{N}_{26}-\mathrm{C}_{29}$ terminal $\beta$-alanine.

$7.32(\mathrm{~m}, 5 \mathrm{H}) ; 62.5 \mathrm{MHz}{ }^{13} \mathrm{C} \mathrm{NMR}\left(\mathrm{CDCl}_{3}\right) \delta 17.6,28.7,34.0$, $34.7,46.2,46.8,67.1,128.0,128.4,136.1,156.1,173.1,175.1$. Anal. Calcd for $\mathrm{C}_{16} \mathrm{H}_{20} \mathrm{~N}_{2} \mathrm{O}_{5}$ : C, 59.97; $\mathrm{H}, 6.30 ; \mathrm{N}, 8.75$. Found: C, 59.93; H, 6.19; N, 8.65

Amine 6. A mixture of dipeptide $3^{7 \mathrm{~b}}(360 \mathrm{mg}, 1.1 \mathrm{mmol})$ and $10 \% \mathrm{Pd} / \mathrm{C}(77 \mathrm{mg})$ in methanol $(15 \mathrm{~mL})$ was stirred at room temperature overnight under 2 atm of hydrogen pressure. The reaction mixture was filtered through Celite that was sucessively washed with several portions of dichloromethane. Solvents were removed under vacuo from the combined filtrates to afford amine 6 as an oil (220 mg, 100\% yield) that was used in the coupling step without further purification: $[\alpha]_{D}$ -6 (c 1.5, MeOH); IR (film) 3439, 1736, $1600 \mathrm{~cm}^{-1} ; 250 \mathrm{MHz}$ ${ }^{1} \mathrm{H}$ NMR (methanol- $\left.\mathrm{d}_{4}\right) \delta 1.57(\mathrm{~m}, 2 \mathrm{H}), 1.96(\mathrm{~m}, 2 \mathrm{H}), 2.20(\mathrm{~m}$, $1 \mathrm{H}), 2.52 \mathrm{~m}, 2 \mathrm{H}), 3.32(\mathrm{~m}, 1 \mathrm{H}), 3.41(\mathrm{~m}, 2 \mathrm{H}), 3.66(\mathrm{~s}, 3 \mathrm{H}) ; 62.5$ $\mathrm{MHz}{ }^{13} \mathrm{C}$ NMR (methanol- $\mathrm{d}_{4}$ ) $\delta 17.7,28.7,34.1,34.6,46.3,46.7$, $67.1,128.1,128.5,136.1,156.1,172.9,175.2$.

Tetrapeptide 5. Hydroxybenzotriazole $(78 \mathrm{mg}, 1.0 \mathrm{mmol})$ and DEC hydrochloride (535 mg, $3.4 \mathrm{mmol}$ ) were successively added to a solution containing acid $\mathbf{4}(370 \mathrm{mg}, 1.2 \mathrm{mmol}$ ) and amine 6 (230 mg, $1.1 \mathrm{mmol})$ in freshly distilled dry DMF (14 $\mathrm{mL}$ ). The light-protected mixture was stirred at room temperature for $72 \mathrm{~h}$ under nitrogen atmosphere. Then ethyl acetate $(50 \mathrm{~mL}$ ) was added, and the solution was washed with five portions of saturated aqueous $\mathrm{NaHCO}_{3}$. The organic phase was dried over anhydrous $\mathrm{MgSO}_{4}$, and the solvent was removed at reduced pressure to afford tetrapeptide 6 (310 mg, 60\% yield) as a solid that was purified by crystallization: crystals; $\mathrm{mp} 173-175^{\circ} \mathrm{C}$ (from ethyl acetate); $[\alpha]_{\mathrm{D}}-60$ (c $0.5, \mathrm{CHCl}_{3}$ ); IR (film) 3308, 1734, 1689, $1642 \mathrm{~cm}^{-1} ; 500 \mathrm{MHz}{ }^{1} \mathrm{H}$ NMR $\left(\mathrm{CDCl}_{3}\right) \delta 1.98(\mathrm{~m}, 2 \mathrm{H}), 2.15(\mathrm{~m}, 3 \mathrm{H}), 2.26(\mathrm{~m}, 3 \mathrm{H}), 2.36(\mathrm{~m}$ $2 \mathrm{H}), 2.51(\mathrm{~m}, 2 \mathrm{H}), 3.18(\mathrm{~m}, 1 \mathrm{H}), 3.30(\mathrm{~m}, 2 \mathrm{H}), 3.49(\mathrm{~m}, 2 \mathrm{H})$, $3.62(\mathrm{~m}, 1 \mathrm{H}), 3.72(\mathrm{~s}, 3 \mathrm{H}), 4.48(\mathrm{q}, \mathrm{J}=8.5 \mathrm{~Hz}, 1 \mathrm{H}), 4.63(\mathrm{q}, \mathrm{J}$ $=8.5 \mathrm{~Hz}, 1 \mathrm{H}), 5.03(\mathrm{~d}, \mathrm{~J}=12 \mathrm{~Hz}, 1 \mathrm{H}), 5.11(\mathrm{~d}, \mathrm{~J}=12 \mathrm{~Hz}$, $1 \mathrm{H}), 6.11(\mathrm{~d}, \mathrm{~J}=9.0 \mathrm{~Hz}, 1 \mathrm{H}), 6.40 \mathrm{t}, \mathrm{J}=6.0 \mathrm{~Hz}, 1 \mathrm{H}), 6.88(\mathrm{t}$ $\mathrm{J}=6.0 \mathrm{~Hz}, 1 \mathrm{H}), 7.18(\mathrm{~d}, \mathrm{~J}=8.2 \mathrm{~Hz}, 1 \mathrm{H}), 7.32(\mathrm{~m}, 5 \mathrm{H}) ; 62.5$ $\mathrm{MHz}{ }^{13} \mathrm{C} \mathrm{NMR}\left(\mathrm{CDCl}_{3}\right) \delta 18.3,19.0,28.5,28.6,33.7,34.8,35.0$, 35.7, 45.3, 45.5, 45.9, 46.7, 51.7, 66.4, 128.0, 128.5, 136.5, 155.8, 171.2, 172.7, 172.9, 173.1; HRMS (EI, $70 \mathrm{eV})$ calcd for $\mathrm{C}_{25} \mathrm{H}_{34} \mathrm{~N}_{4} \mathrm{O}_{7} 502.2616$, found 502.2428 .
Tripeptide 7. Following the same procedure described above for the preparation of $\mathbf{5}$, tripeptide $\mathbf{7}$ was synthesized from amine 6 (140 mg, $0.7 \mathrm{mmol}$ ) and $\mathrm{N}-\mathrm{Cbz}-\beta$-Ala $(235 \mathrm{mg}$, $1.0 \mathrm{mmol}$ ) as a solid: yield $97 \mathrm{mg}(34 \%)$; crystals; $\mathrm{mp} 127-$ $130{ }^{\circ} \mathrm{C}$ (ethyl acetate-pentane); $[\alpha]_{\mathrm{D}}-28$ (c 1.0, MeOH); IR (film) 3431, 1730, 1705, $1656 \mathrm{~cm}^{-1} ; 250 \mathrm{M} \mathrm{Hz}^{1} \mathrm{H} \mathrm{NMR}\left(\mathrm{CDCl}_{3}\right)$ $\delta 1.58(\mathrm{~m}, 2 \mathrm{H}), 2.15(\mathrm{~m}, 2 \mathrm{H}), 2.29(\mathrm{~m}, 1 \mathrm{H}), 2.36(\mathrm{~m}, 2 \mathrm{H}), 2.52$ $(\mathrm{m}, 2 \mathrm{H}), 3.23(\mathrm{~m}, 2 \mathrm{H}), 3.44(\mathrm{~m}, 3 \mathrm{H}), 3.67(\mathrm{~s}, 3 \mathrm{H}), 5.06(\mathrm{~s}, 2 \mathrm{H})$ 5.60 (broad s, 1H), 5.97 (broad s, 1H), 6.16 (broad s, 1H), 7.36 $(\mathrm{m}, 5 \mathrm{H}) ; 62.5 \mathrm{M} \mathrm{Hz}^{13} \mathrm{C} \mathrm{NMR}\left(\mathrm{CDCl}_{3}\right) \delta 22.4,28.7,33.8,34.8$, 35.6, 38.7, 44.6, 45.7, 51.8, 66.5, 127.9, 128.0, 128.5, 136.6, 156.5, 171.3, 172.8. 173.1; MS (EI, $70 \mathrm{eV}) \mathrm{m} / \mathrm{z} 405\left(\mathrm{M}^{+}, 6\right), 298$ (24), 195 (28), 91 (100).

NMR Studies on Tetrapeptide 5. All 1D, 2D (COSY, NOESY HSQC, and HMBC experiments), and diffusion NMR spectra were performed on a $500 \mathrm{MHz}$ spectrometer equipped with a $5 \mathrm{~mm}$ triple-resonance inverse probehead incorporating pulsed-field gradients in the z-direction. NMR spectra were registered in $\mathrm{CDCl}_{3}$ or $\mathrm{DMSO}-\mathrm{d}_{6}$, and chemical shifts are given in parts per million ( $\delta$ scale).

NMR diffusion experiments were recorded using the LED pulse scheme with bipolar gradients ${ }^{20}$ without temperature calibration in order to minimize undesired convection effects. ${ }^{21}$ Similar results were also obtained using the double STE pulse sequence. A series of 1D diffusion experiments were recorded with several diffusion times ranging from 100 ms to 1s in order to observe the different intensity decay for each $\mathrm{NH}$ resonance and thus to extract qualitative information about hydrogen bonding strength. The duration of each z-gradient was set to $1.5 \mathrm{~ms}$ and data were acquired with $16 \mathrm{~K}$ using a recyde delay of $1.5 \mathrm{~s}$. Data were processed using a line broadening of 0.5 $\mathrm{Hz}$. Complete structural characterization using the described COSY, HSQC, NOESY, and diffusion experiments was performed on both $\mathrm{CDCl}_{3}$ and DMSO-d $\mathrm{d}_{6}$ solutions (see the Supporting Information for more details). 260

(20) Wu, D.; Chen, A.; J ohnson, C. S. J . Magn. Reson. A 1995, 115,

(21) Esturau, N.; Sánchez-Ferrando, F.; Gavin, J . A.; Roumestand C.; Delsuc, M. A.; Parella, T. J. Magn. Reson. 2001, 153, 48. 
Molecular Modeling Studies. Conformational Search. All calculations were run on a SGI workstation (R4000, 128 MB RAM, 19 GB hard disk) under an Irix 5.3 operating system. Molecular mechanics calculations were carried out with Spartan v 5.0 and Insight II discover 3.0 v1997.

Iterative Simulated Annealing (ISA). The calculations were carried out within the molecular mechanics using the CFF 91 force field implemented in DISCOVER v.97. They were conducted under vacuum with a distance-dependent dielectric constant $(4 r)$ and a cutoff of $13 \AA$. Starting from extended structures of the tetrapeptide $\mathbf{5}$, the structure was minimized and subsequently heated to $900 \mathrm{~K}$ in a very short period of time. The structure was then cooled slowly to $100 \mathrm{~K}$ and minimized. In our case, the heating was carried out in steps. At each step the temperature was raised $100 \mathrm{~K}$ in $0.1 \mathrm{ps}$ and following heating the system was allowed to stay 1 ps at the new temperature. The system was allowed to stand for 10 ps at $1000 \mathrm{~K}$ and then cooled in steps. At each step, the temperature was lowered $100 \mathrm{~K}$ in $0.1 \mathrm{ps}$ and after cooling the system was all owed to stay 10 ps at the new temperature. This structure is the starting conformation for another cycle, creating a library of conformations that are rank ordered by energy every 150 cycles. To determi ne the conformer families, all the backbone atoms from $\mathrm{C}_{9}$ to $\mathrm{C}_{29}$ were considered. The procedure was repeated until no new conformations appeared after a predetermined number of cycles (in our case five times) within a $2 \mathrm{kcal} / \mathrm{mol}$ energy range with respect to the lowest energy structure al ready found. Heating must be carried out rapidly in order to make the molecule jump to a different region in the space. In contrast, cooling was slow in order to obtain the lowest energy minimum of the region. This protocol was run several times (five), employing fully extended starting structures of 5 .
Molecular Dynamics. The resulting lowest energy conformer of tetrapeptide $\mathbf{5}$ (resulting from the Iterative Simulated Annealing) was used as starting structure for a molecular dynamics calculation using an explicit solvent model in chloroform. NVT calculation at $298 \mathrm{~K}$ was performed using a cubic box of $48 \AA$ side length and 433 chloroform molecules. Periodic bounded conditions were applied. After heating and equilibration of the system for 0.25 ns, evolution time was 0.75 ns. 750 structures were saved periodically for further trajectory analysis.

Acknowledgment. S.I. thanks the UAB for a predoctoral fellowship. Financial support from MCyTFEDER (BQU2001-1907, BI O2002-2301, and BQU200301677) and Generalitat de Catalunya (2001SGR00182, 2001SGR00047) is gratefully acknowledged.

Supporting Information Available: Cartesian coordinates of tetrapeptide $\mathbf{5}$ obtained by using the CFF91 and B3LYP methods. Distances between hydrogen atoms for energy minima conformers. ${ }^{1} \mathrm{H}$ and ${ }^{13} \mathrm{C}$ assignments in DMSO$\mathrm{d}_{6}$ at $298 \mathrm{~K},{ }^{1} \mathrm{H}$ NMR spectrum in $\mathrm{CDCl}_{3}$ at different temperatures, ${ }^{1} \mathrm{H}$ NMR spectrum in DMSO-d 6 at $298 \mathrm{~K}, 2 \mathrm{D}{ }^{1} \mathrm{H}-{ }^{1} \mathrm{H}$ spectra, 2D ${ }^{1} \mathrm{H}-{ }^{1} \mathrm{H}$ NOESY spectra, 2D gradient-enhanced ${ }^{1} \mathrm{H}-{ }^{1} \mathrm{H}$ COSY and NOESY spectra, 2D gradient-enhanced phase-sensitive ${ }^{1} \mathrm{H}-{ }^{13} \mathrm{C}$ HSQC spectra, temperature coefficients, and self-diffusion NMR studies for tetrapeptide $5 .{ }^{1} \mathrm{H}$ NMR for amine $\mathbf{6}$ and tripeptide 7. This material is available free of charge via the Internet at http://pubs.acs.org.

J 00497555 